九州大学学術情報リポジトリ

Kyushu University Institutional Repository

\title{
Responses of Soybean and Cucumber Plants to Nacland CaCl2 Salinity in Nitrate and Enhanced Ammonium Nutrition
}

Dabuxi latu

Laboratory of Plant Nutrition, Division of Soil Science and Plant Production, Department of Plant Resouces, Graduate School of Bioresource and Bioenvironmetal Sciences, Kyushu Unviersity

Ikeda, Motoki

Laboratory of Plant Nutrition, Division of Soil Science and Plant Production, Department of Plant Resoruces, Faculty of Agriculture, Kyushu Unviersity

https://doi.org/10.5109/4581

出版情報：九州大学大学院農学研究院紀要. 49 (2)，pp.217-224，2004-10-01. Faculty of Agriculture, Kyushu University バージョン：

権利関係 : 


\title{
Responses of Soybean and Cucumber Plants to $\mathrm{NaCl}$ and $\mathrm{CaCl}_{2}$ Salinity in Nitrate and Enhanced Ammonium Nutrition
}

\author{
DABUXILATU' ${ }^{1}$ and Motoki IKEDA* \\ Laboratory of Plant Nutrition, Division of Soil Science and Plant Production, \\ Department of Plant Resources, Faculty of Agriculture, \\ Kyushu University, Fukuoka 812-8581, Japan \\ (Received June 15, 2004 and accepted July 13, 2004)
}

\begin{abstract}
The effect of nitrate $\left(4 \mathrm{mM} \mathrm{NO}_{3}^{-}\right)$and enhanced ammonium $\left(3.5 \mathrm{mM} \mathrm{NH}_{4}^{+}+0.5 \mathrm{mM} \mathrm{NO}_{3}^{-}\right)$ nutrition on the growth of soybean and cucumber plants grown hydroponically at two levels (25 and $50 \mathrm{mM} \mathrm{Cl}$ ) of $\mathrm{NaCl}$ and $\mathrm{CaCl}_{2}$ salinity stress was investigated. The growth of both plants was better in nitrate nutrition than in enhanced ammonium nutrition. The $\mathrm{pH}$ values for enhanced ammonium solution decreased similarly for both plants regardless of salinity stress. In nitrate nutrition, lower salinity did not affect soybean growth, whereas higher salinity clearly suppressed its growth. In the case of nitrate-fed cucumber plants, dry matter production was not decreased by the addition of $\mathrm{CaCl}_{2}$ but was by the addition of $\mathrm{NaCl}$. In enhanced ammonium nutrition, the extent of growth suppression due to salinity was only small in soybean and cucumber plants. In both plants, trends in increases in the concentrations of $\mathrm{Na}, \mathrm{Ca}$ and $\mathrm{Cl}$ in leaf parts caused by $\mathrm{NaCl}$ and $\mathrm{CaCl}_{2}$ salinity were similar in both nitrate nutrition and enhanced ammonium nutrition. Leaf $\mathrm{Na}$ concentrations did not increase in soybean plants but did in cucumber plants. Leaf $\mathrm{N}$ concentrations that were higher in enhanced ammonium nutrition than in nitrate nutrition were not affected by salinity treatments. These results suggest that the acidity of the solution rather than the high levels of added salts affects plant growth in enhanced ammonium nutrition, and therefore, the effect of salinity on plant growth is less discernable in enhanced ammonium nutrition.
\end{abstract}

\section{INTRODUCTION}

Tolerance to salinity considerably varies among plant species and depends on the plant's ability to control salt uptake from media, such as soil, and to translocate salt from root to shoot and to effectively compartmentalize the salt at the cellular levels (Munns, 2002). In our previous study, we investigated the sensitivity of soybean and cucumber plants that were grown using nitrate as the source of N (Dabuxilatu and Ikeda, 2003). Soybean was shown to have a higher sensitivity to $\mathrm{Cl}$ than cucumber. Soybean also demonstrated a greater ability to restrict translocation of $\mathrm{Na}$ from root to leaf. As a result, $\mathrm{Na}$ toxicity is unlikely to be observed in the leaf of soybean. In contrast, cucumber was found to be tolerant to $\mathrm{Cl}$ and sensitive to $\mathrm{Na}$ (Dabuxilatu and Ikeda, 2003).

It is well recognized that ammonium nutrition results in lower concentrations of cationic minerals in each organ of various plants compared to nitrate nutrition (Van

\footnotetext{
1 Laboratory of Plant Nutrition, Division of Soil Science and Plant Production, Department of Plant Resources, Graduate School of Bioresource and Bioenvironmetal Sciences, Kyushu University, Fukuoka 812-8581, Japan

* Corresponding author (E-mail: ikedam@agr.kyushu-u.ac.jp)
} 
Beusichem et al., 1988). Several researchers reported the effect of nitrogen sources on the growth of various plant species grown under saline conditions (Silberbush and Lips 1988; Bourgeais-Chaillow et al., 1992; Leidi et al., 1991; Lewis et al., 1989; Hawkins and Lips, 1989; Speer et al., 1994; Speer and Kaiser, 1994; Ashraf, 1999; Ashraf and Sultana, 2000; Al-Mutawa and El-Katony, 2001). The supply of ammonium nitrogen increased the sensitivity of wheat, maize and pea plants to salinity (Lewis et al., 1989; Speer et al., 1994). Shoot dry weight of wheat plants was not affected by nitrogen sources under salinity stress (Leidi et al., 1991). In soybean, root and stem biomass were not decreased by $\mathrm{NaCl}$ but leaf biomass was in both nitrate and ammonium media (Bourgeais-Chaillow et al., 1992). Peanuts grew better in ammonium media than nitrate media under saline conditions (Silberbush and Lips, 1988). The biomass production of nitrate-supplied wheat was reduced by $\mathrm{NaCl}$ stress to a greater extent than that of ammonium-supplied wheat, and increasing $\mathrm{Ca}$ concentration in nutrient media resulted in an increase in biomass production of $\mathrm{NaCl}$-stressed, nitrate-supplied plants but this was not the case for ammonium-supplied plants (Hawkins and Lewis, 1993).

In this study, we compared the growth and mineral accumulation in soybean and cucumber plants grown in nitrate and enhanced ammonium nutrition with high concentrations of $\mathrm{NaCl}$ and $\mathrm{CaCl}_{2}$.

\section{MATERIALS AND METHODS}

Soybean (Glycine $\max$ L. Merrill cv. Fukuyutaka) seeds that had been sterilized with $\mathrm{NaClO}$ solution ( $0.5 \%$ effective chlorine) and cucumber (Cucumis sativus L. cv. Chojitsuochiai Nigou) seeds sterilized with a fungicide by the producer were germinated for 2 days on filter paper in petri dishes at $25^{\circ} \mathrm{C}$ in the dark. The germinated seeds were transplanted into vermiculite moistened with tap water and grown for 13 days. Seedlings of both plants were then transferred individually to 3 -L pots containing one-fourth strength aerated Hoagland nutrient solution ( $\mathrm{pH}$ 6.0) (Downs and Hellmers, 1975; Ikeda et al., 1992). At this stage, the soybean seedlings had fully expanded primary leaves and the cucumber the first leaf. Both plants were grown under natural greenhouse conditions in Kyushu University during the summer months. In both cases, the nitrogen source was $4 \mathrm{mM} \mathrm{NaNO}_{3}$ prior to the initiation of salt treatment.

Twenty-day-old soybean plants were subjected to salt treatment for 11 days and 23-day-old cucumber plants for 13 days. For both nitrate $\left(4 \mathrm{mM} \mathrm{NaNO}_{3}\right)$ and enhanced ammonium $\left(1.75 \mathrm{mM}\left(\mathrm{NH}_{4}\right)_{2} \mathrm{SO}_{4}+0.5 \mathrm{mM} \mathrm{NaNO}_{3}\right)$ nutrition, the salinity was imposed by adding the appropriate salts to the growth medium in order to give the selected concentrations; 25 and $50 \mathrm{mM}$ for $\mathrm{NaCl}$ and 12.5 and $25 \mathrm{mM}$ for $\mathrm{CaCl}_{2}$. Controls and treatment pots were set in triplicate. The nutrient solution was renewed every 3 days. Prior to changing, the $\mathrm{pH}$ was measured using a $\mathrm{pH}$ meter (HM-1K, TOA Electronics Ltd., Tokyo).

Harvested plants were washed with water and separated into root, stem (plus petiole) and leaf parts. All the plant parts were dried at $70^{\circ} \mathrm{C}$ for 3 days. After the dry weight was recorded, these materials were milled. Chloride from powdered samples was extracted in water at $45^{\circ} \mathrm{C}$ and the levels determined by ion chromatography (ICA-5000 system, TOA Electronics Ltd., Tokyo). Powdered samples were digested by heating with salicylic acid 
$-\mathrm{H}_{2} \mathrm{SO}_{4}-\mathrm{H}_{2} \mathrm{O}_{2}$ (Cataldo et al., 1974) for the determination of $\mathrm{K}, \mathrm{Na}, \mathrm{Ca}, \mathrm{Mg}$ and $\mathrm{N}$. Potassium, $\mathrm{Na}, \mathrm{Ca}$ and $\mathrm{Mg}$ in the digest solution were determined by atomic absorption (Z-5300, Hitachi, Tokyo). Nitrogen in the digest solution was determined by the indophenol method (Cataldo et al., 1974).

\section{RESULTS}

Dry matter production of soybean and cucumber plants is shown in Fig. 1. In the control soybean plants, dry mass of all the organs was greater in nitrate nutrition than in enhanced ammonium nutrition. The supply of $25 \mathrm{mM} \mathrm{NaCl}$ and $12.5 \mathrm{mM} \mathrm{CaCl}_{2}$ did not affect dry mass, but the supply of $50 \mathrm{mM} \mathrm{NaCl}$ and $25 \mathrm{mM} \mathrm{CaCl}_{2}$ clearly decreased dry
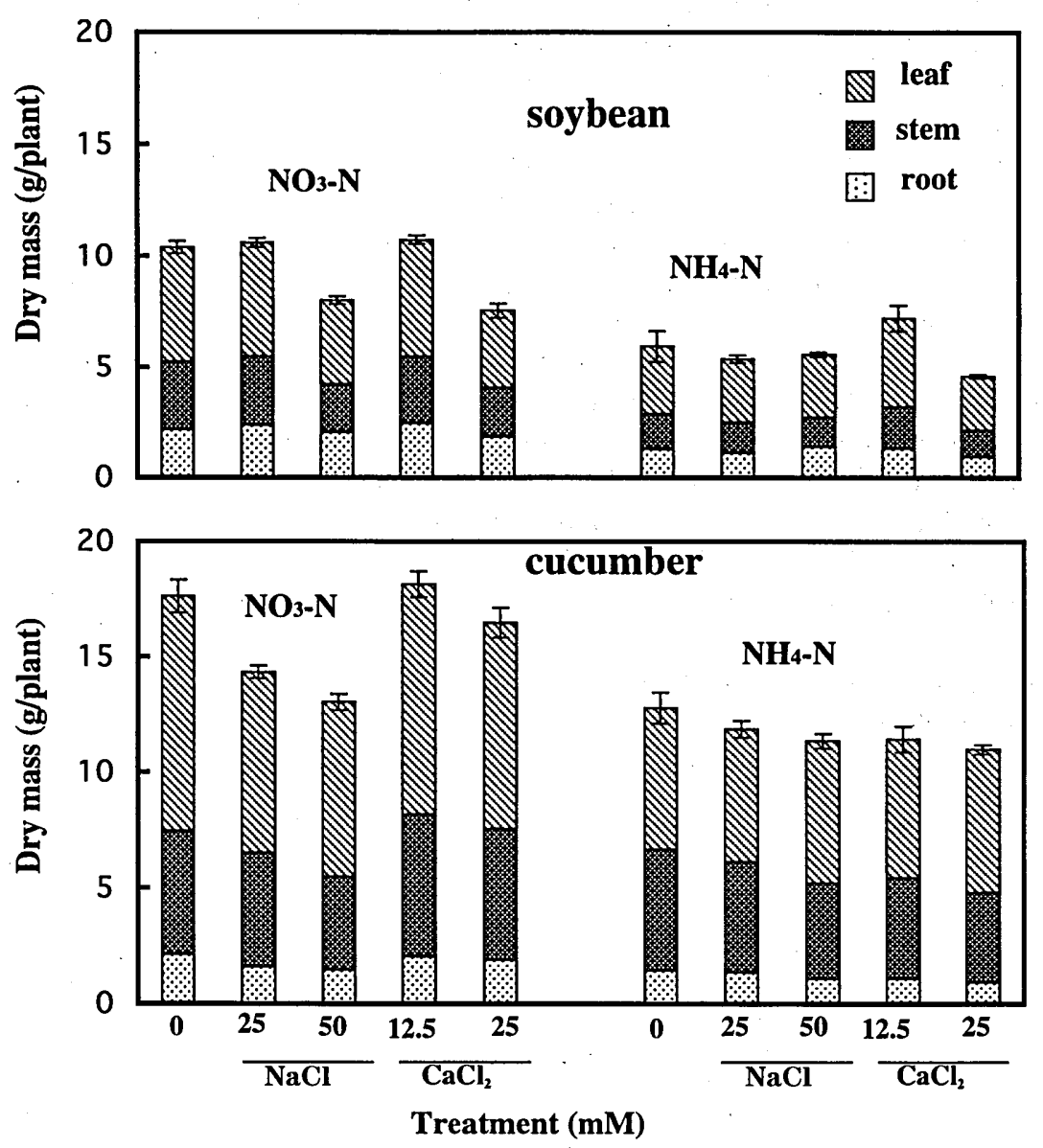

Fig. 1. Effect of salinity and nitrogen sources on dry mass of soybean and cucumber plants. Error bars on columns indicate S. D. of means $(n=3)$. 
mass in nitrate nutrition, particularly in stem + petiole and leaf parts. In enhanced ammonium nutrition, dry mass was slightly decreased by the supply of higher concentrations of both salts, although the supply of $12.5 \mathrm{mM} \mathrm{CaCl}_{2}$ resulted in an increase in dry mass.

The dry mass of cucumber plants was lower in enhanced ammonium nutrition than in nitrate nutrition, especially for leaf and root part (Fig. 1). In nitrate nutrition, the supply of $\mathrm{NaCl}$ clearly decreased dry mass, whereas the supply of $\mathrm{CaCl}_{2}$ had no effect. In the case of enhanced ammonium nutrition, the extent of growth suppression was lower with $\mathrm{NaCl}$ supply than with $\mathrm{CaCl}_{2}$ supply although growth suppression was not marked.

The $\mathrm{pH}$ of the nutrient solution increased from $\mathrm{pH} 6$ to $\mathrm{pH} 8$ in nitrate nutrition for both plants. In the case of enhanced ammonium nutrition, it decreased from $\mathrm{pH} 6$ to $\mathrm{pH} 5$ for soybean and to $\mathrm{pH} 4$ for cucumber during the first period of treatment and to $\mathrm{pH} 4$ for soybean and to $\mathrm{pH} 3$ for cucumber during the final period of treatment. The $\mathrm{pH}$ decreases in enhanced ammonium nutrition were similar for both plants with or without added salts, suggesting that the uptake of ammonium was little affected by added salts. There is a possibility that the lowering of $\mathrm{pH}$ might affect the growth of both plants in the case of enhanced ammonium nutrition regardless of added salts.

When soybean plants were supplied with $\mathrm{NaCl}$, the $\mathrm{Na}$ concentration remained very low in the leaf parts irrespective of nitrogen nutrition conditions, whereas it increased in the root and stem. This increase was found to be related to the concentration of $\mathrm{NaCl}$ supplied (Table 1). In the case of cucumber, $\mathrm{Na}$ concentrations in all the plant parts including the leaf were greatly increased by the supply of $\mathrm{NaCl}$.

The supply of $\mathrm{NaCl}$ and $\mathrm{CaCl}_{2}$ greatly increased $\mathrm{Cl}$ concentrations in all the parts of both plants (Table 1). The nature of the added salts and nitrogen sources did not clearly cause consistent differences in the increase of $\mathrm{Cl}$ concentrations. Even in nitrate-fed cucumber plants treated with $25 \mathrm{mM} \mathrm{CaCl}_{2}$, despite the extremely high observed $\mathrm{Cl}$ levels, the growth was similar to that of the control plants (see Fig. 1).

Mineral concentrations in leaf parts affected by the supply of $\mathrm{NaCl}$ and $\mathrm{CaCl}_{2}$ are shown in Table 2. Potassium concentrations were decreased by the supply of $\mathrm{NaCl}$ in

Table 1. Effect of $\mathrm{NaCl}$ and $\mathrm{CaCl}_{2}$ on the leaf $\mathrm{Na}$ and $\mathrm{Cl}$ concentrations in soybean and cucumber plants grown in different nitrogen nutrition.

\begin{tabular}{|c|c|c|c|c|c|}
\hline \multirow[t]{2}{*}{ Treatment } & \multirow[b]{2}{*}{$(\mathrm{mM})$} & \multicolumn{2}{|c|}{ Soybean } & \multicolumn{2}{|c|}{ Cucumber } \\
\hline & & $\mathrm{Na}$ & $\mathrm{Cl}$ & $\mathrm{Na}$ & $\mathrm{Cl}$ \\
\hline & & \multicolumn{4}{|c|}{ (g/kg dry matter) } \\
\hline $\mathrm{N}$ control & - & $0.15 \pm 0.05$ & $14.5 \pm 0.8$ & $2.7 \pm 0.4$ & $6.3 \pm 0.4$ \\
\hline $\mathrm{N} \mathrm{NaCl}$ & 25 & $0.33 \pm 0.23$ & $20.1 \pm 1.1$ & $11.4 \pm 3.5$ & $22.3 \pm 1.2$ \\
\hline $\mathrm{N} \mathrm{NaCl}$ & 50 & $0.22 \pm 0.12$ & $21.2 \pm 1.2$ & $14.2 \pm 0.7$ & $29.2 \pm 1.6$ \\
\hline $\mathrm{N} \mathrm{CaCl}_{2}$ & 12.5 & $0.25 \pm 0.16$ & $22.8 \pm 1.3$ & $2.1 \pm 0.5$ & $22.9 \pm 2.3$ \\
\hline $\mathrm{N} \mathrm{CaCl}_{2}$ & 25 & $0.22 \pm 0.19$ & $18.2 \pm 1.0$ & $1.9 \pm 0.5$ & $32.2 \pm 1.8$ \\
\hline A control & - & $0.10 \pm 0.01$ & $10.4 \pm 0.6$ & $2.0 \pm 0.2$ & $14.3 \pm 0.8$ \\
\hline $\mathrm{A} \mathrm{NaCl}$ & 25 & $0.23 \pm 0.09$ & $18.6 \pm 1.0$ & $10.7 \pm 0.4$ & $36.7 \pm 3.0$ \\
\hline $\mathrm{A} \mathrm{NaCl}$ & 50 & $0.31 \pm 0.01$ & $29.1 \pm 1.6$ & $25.7 \pm 0.7$ & $40.2 \pm 2.2$ \\
\hline $\mathrm{A} \mathrm{CaCl}_{2}$ & 12.5 & $0.20 \pm 0.15$ & $22.6 \pm 1.3$ & $2.6 \pm 0.3$ & $31.8 \pm 1.8$ \\
\hline $\mathrm{A} \mathrm{CaCl}_{2}$ & 25 & $0.20 \pm 0.15$ & $31.9 \pm 1.8$ & $1.8 \pm 0.2$ & $36.4 \pm 2.0$ \\
\hline
\end{tabular}

$\mathrm{N}$ : nitrate nutrition, A: enhanced ammonium nutrition; Data are shown as means $\pm \mathrm{S} . \mathrm{D} .(n=3)$. 
cucumber, but not in soybean regardless of the nitrogen source. The supply of $\mathrm{CaCl}_{2}$ slightly decreased $\mathrm{K}$ concentrations in soybean, but not in cucumber. Ca concentrations in both plants were increased by the supply of $\mathrm{CaCl}_{2}$ in both types of nitrogen nutrition, but the supply of $\mathrm{NaCl}$ did not show a consistent trend with regards to Ca concentrations. Magnesium concentrations were decreased by the supply of $\mathrm{CaCl}_{2}$ while added $\mathrm{NaCl}$ afforded little effect on $\mathrm{Mg}$ concentrations in both plants.

In both plants, leaf nitrogen concentrations appeared higher in enhanced ammonium nutrition than in nitrate nutrition. Salinity treatment with $\mathrm{NaCl}$ and $\mathrm{CaCl}_{2}$ did not affect leaf nitrogen concentrations (Table 2).

Mineral accumulation in soybean and cucumber plants grown in nitrate and enhanced ammonium nutrition under salt-stress conditions is shown in Table 3. $\mathrm{K}$ accumulation in soybean was greatly lowered by the addition of the higher concentration of either $\mathrm{NaCl}$ or $\mathrm{CaCl}_{2}$ in both the nitrogen nutrition conditions while it was lowered in cucumber only by the addition of $\mathrm{NaCl}$ irrespective of different nitrogen nutrition. In both plants, $\mathrm{Ca}$ accumulation was, as a whole, increased by the addition of $\mathrm{CaCl}_{2}$. In the case of enhanced ammonium nutrition, this increase did not always show a dependence on the treatment concentration of $\mathrm{CaCl}_{2}$. Only $\mathrm{NaCl}$ treatment in nitrate-fed soybean plants reduced $\mathrm{Ca}$ accumulation. Supply of $\mathrm{NaCl}$ and $\mathrm{CaCl}_{2}$ reduced $\mathrm{Mg}$ accumulation except for soybean plants grown in enhanced ammonium nutrition. The extent of increases of $\mathrm{Na}$ accumulation was large compared to that of $\mathrm{Cl}$ accumulation in both plants. There was

Table 2. Effect of $\mathrm{NaCl}$ and $\mathrm{CaCl}_{2}$ on $\mathrm{K}, \mathrm{Ca}, \mathrm{Mg}$, and $\mathrm{N}$ concentrations in the leaf part of soybean and cucumber plants grown in different nitrogen nutrition.

\begin{tabular}{|c|c|c|c|c|c|}
\hline \multirow[t]{2}{*}{ Treatment } & & $\mathrm{K}$ & $\mathrm{Ca}$ & $\mathrm{Mg}$ & $\mathrm{N}$ \\
\hline & $(\mathrm{mM})$ & \multicolumn{4}{|c|}{ (g/kg dry matter) } \\
\hline & & \multicolumn{4}{|c|}{ Soybean } \\
\hline $\mathrm{N}$ control & - & $20.4 \pm 1.3$ & $23.2 \pm 3.0$ & $5.2 \pm 0.3$ & $47.6 \pm 1.7$ \\
\hline $\mathrm{N} \mathrm{NaCl}$ & 25 & $22.2 \pm 3.4$ & $13.8 \pm 0.7$ & $4.6 \pm 0.2$ & $47.6 \pm 0.9$ \\
\hline $\mathrm{N} \mathrm{NaCl}$ & 50 & $21.3 \pm 0.8$ & $15.0 \pm 4.7$ & $4.8 \pm 0.1$ & $45.7 \pm 1.9$ \\
\hline $\mathrm{N} \mathrm{CaCl}_{2}$ & 12.5 & $17.2 \pm 1.3$ & $24.6 \pm 4.4$ & $3.9 \pm 0.1$ & $44.4 \pm 1.3$ \\
\hline $\mathrm{N} \mathrm{CaCl}_{2}$ & 25 & $16.2 \pm 1.0$ & $28.5 \pm 1.4$ & $3.6 \pm 0.2$ & $41.4 \pm 1.9$ \\
\hline A control & - & $24.6 \pm 4.9$ & $8.8 \pm 3.5$ & $3.9 \pm 0.2$ & $48.1 \pm 1.0$ \\
\hline $\mathrm{A} \mathrm{NaCl}$ & 25 & $26.7 \pm 1.0$ & $10.0 \pm 3.2$ & $4.2 \pm 0.1$ & $55.9 \pm 1.5$ \\
\hline $\mathrm{A} \mathrm{NaCl}$ & 50 & $28.8 \pm 1.2$ & $15.1 \pm 4.2$ & $5.2 \pm 0.2$ & $57.4 \pm 0.8$ \\
\hline $\mathrm{A} \mathrm{CaCl}{ }_{2}$ & 12.5 & $20.5 \pm 0.9$ & $20.8 \pm 5.3$ & $3.8 \pm 0.1$ & $52.2 \pm 1.5$ \\
\hline \multirow[t]{2}{*}{$\mathrm{A} \mathrm{CaCl}_{2}$} & 25 & $20.3 \pm 0.7$ & $26.2 \pm 6.3$ & $4.0 \pm 0.4$ & $47.8 \pm 3.9$ \\
\hline & & \multicolumn{4}{|c|}{ Cucumber } \\
\hline $\mathrm{N}$ control & - & $31.1 \pm 1.2$ & $33.5 \pm 2.5$ & $4.7 \pm 1.0$ & $38.9 \pm 5.1$ \\
\hline $\mathrm{N} \mathrm{NaCl}$ & 25 & $25.3 \pm 3.5$ & $42.1 \pm 2.2$ & $4.7 \pm 0.5$ & $44.5 \pm 4.6$ \\
\hline $\mathrm{N} \mathrm{NaCl}$ & 50 & $21.6 \pm 2.4$ & $41.4 \pm 6.7$ & $5.3 \pm 0.2$ & $40.3 \pm 3.6$ \\
\hline $\mathrm{N} \mathrm{CaCl}_{2}$ & 12.5 & $31.1 \pm 3.0$ & $53.2 \pm 4.4$ & $3.4 \pm 0.2$ & $42.1 \pm 0.7$ \\
\hline $\mathrm{N} \mathrm{CaCl}_{2}$ & 25 & $32.3 \pm 4.2$ & $70.5 \pm 1.7$ & $3.5 \pm 0.3$ & $47.4 \pm 1.3$ \\
\hline A control & - & $37.0 \pm 3.2$ & $35.1 \pm 1.5$ & $3.6 \pm 0.4$ & $56.6 \pm 2.0$ \\
\hline $\mathrm{A} \mathrm{NaCl}$ & 25 & $27.7 \pm 1.2$ & $33.1 \pm 2.3$ & $3.3 \pm 0.2$ & $54.8 \pm 1.8$ \\
\hline $\mathrm{A} \mathrm{NaCl}$ & 50 & $23.7 \pm 3.0$ & $36.2 \pm 1.0$ & $2.8 \pm 0.1$ & $53.3 \pm 3.7$ \\
\hline $\mathrm{A} \mathrm{CaCl}_{2}$ & 12.5 & $32.8 \pm 0.8$ & $45.5 \pm 0.7$ & $2.9 \pm 0.3$ & $56.5 \pm 1.1$ \\
\hline $\mathrm{A} \mathrm{CaCl}_{2}$ & 25 & $36.0 \pm 7.4$ & $53.1 \pm 2.1$ & $2.9 \pm 0.1$ & $53.0 \pm 1.7$ \\
\hline
\end{tabular}

$\mathrm{N}$ : nitrate nutrition, A: enhanced ammonium nutrition; Data are shown as means $\pm \mathrm{S}$. D. $(n=3)$. 
Table 3. Effect of salinity on mineral content of soybean and cucumber plants grown in different nitrogen nutrition.

\begin{tabular}{|c|c|c|c|c|c|c|}
\hline Treatment & $(\mathrm{mM})$ & $\mathrm{K}$ & $\mathrm{Ca}$ & $\begin{array}{c}\mathrm{Mg} \\
\text { (mg per plant) }\end{array}$ & $\mathrm{Na}$ & $\mathrm{Cl}$ \\
\hline & & \multicolumn{5}{|c|}{ Soybean } \\
\hline $\mathrm{N}$ control & - & 304 & 176 & 57 & 8 & 128 \\
\hline $\mathrm{N} \mathrm{NaCl}$ & 25 & 298 & 120 & 54 & 35 & 206 \\
\hline $\mathrm{N} \mathrm{NaCl}$ & 50 & 210 & 92 & 41 & 70 & 212 \\
\hline $\mathrm{N} \mathrm{CaCl}_{2}$ & 12.5 & 269 & 213 & 50 & 6 & 243 \\
\hline $\mathrm{N} \mathrm{CaCl}_{2}$ & 25 & 187 & 165 & 34 & 4 & 175 \\
\hline A control & - & 190 & 53 & 21 & 5 & 66 \\
\hline $\mathrm{A} \mathrm{NaCl}$ & 25 & 171 & 50 & 21 & 26 & 114 \\
\hline $\mathrm{A} \mathrm{NaCl}$ & 50 & 142 & 61 & 24 & 80 & 184 \\
\hline $\mathrm{A} \mathrm{CaCl}_{2}$ & 12.5 & 205 & 130 & 29 & 5 & 145 \\
\hline $\mathrm{A} \mathrm{CaCl}_{2}$ & 25 & 127 & 108 & 19 & 3 & 137 \\
\hline \multicolumn{7}{|c|}{ Cucumber } \\
\hline $\mathrm{N}$ control & - & 818 & 475 & 86 & 83 & 181 \\
\hline $\mathrm{N} \mathrm{NaCl}$ & 25 & 554 & 453 & 64 & 250 & 383 \\
\hline $\mathrm{N} \mathrm{NaCl}$ & 50 & 421 & 423 & 66 & 302 & 496 \\
\hline $\mathrm{N} \mathrm{CaCl}_{2}$ & 12.5 & 848 & 728 & 76 & 53 & 446 \\
\hline $\mathrm{N} \mathrm{CaCl}_{2}$ & 25 & 841 & 824 & 68 & 42 & 550 \\
\hline A control & - & 567 & 278 & 41 & 37 & 282 \\
\hline $\mathrm{A} \mathrm{NaCl}$ & 25 & 417 & 245 & 34 & 202 & 380 \\
\hline $\mathrm{A} \mathrm{NaCl}$ & 50 & 350 & 273 & 33 & 327 & 514 \\
\hline $\mathrm{A} \mathrm{CaCl}{ }_{2}$ & 12.5 & 479 & 404 & 31 & 30 & 446 \\
\hline $\mathrm{A} \mathrm{CaCl}_{2}$ & 25 & 508 & 452 & 30 & 23 & 473 \\
\hline
\end{tabular}

$\mathrm{N}$ : nitrate nutrition, A: enhanced ammonium nutrition.

little difference in $\mathrm{Cl}$ accumulation between $\mathrm{NaCl}$ and $\mathrm{CaCl}_{2}$ supply and between nitrate and enhanced ammonium nutrition.

\section{DISCUSSION}

The effects of $\mathrm{NaCl}$ and $\mathrm{CaCl}_{2}$ salinity with the same concentration of $\mathrm{Cl}$ were compared in this study, because the effect of $\mathrm{Cl}$ rather than Ca was expected to appear in the $\mathrm{CaCl}_{2}$ treatment. Enhanced ammonium nitrogen was adopted as the nitrogen source in place of ammonium-only solution since nitrate was reported to be necessary for the synthesis and transport of the plant hormone (Walch-Liu et al., 2000). Nevertheless, even without salt treatments, the growth of enhanced ammonium-fed plants was inferior to that of nitrate-fed plants.

The observed responses of soybean and cucumber plants to $\mathrm{NaCl}$ and $\mathrm{CaCl}_{2}$ in nitrate media were similar to those reported in the previous paper (Dabuxilatu and Ikeda, 2003). In enhanced ammonium nutrition, however, the supply of both salts resulted in slightly reduced growth of plants except for soybean treated with $12.5 \mathrm{mM} \mathrm{CaCl}_{2}$, although the growth of control plants fed with enhanced ammonium nitrogen was already suppressed compared to that of nitrate-fed plants. Hence the extent of growth inhibition due to salinity was less in enhanced ammonium nutrition than in nitrate nutrition. Other studies 
also showed similar results concerning salinity effects on different plants whose growth was inhibited by ammonium nutrition regardless of salinity. These studies, however, did not make reference to $\mathrm{pH}$ changes in ammonium and nitrate media. (Hawkins and Lewis, 1993; Ashraf and Sultana, 2000; Ashraf, 1999). It should be noted that ammonium nutrition induced the lowering of solution $\mathrm{pH}$ unless it was adjusted automatically or frequently. If the solution acidity in enhanced ammonium nutrition increases to a level where it inhibits root growth during salinity treatment, the low $\mathrm{pH}$ might affect the growth of the plant to a greater extent than the tested level of salinity. The $\mathrm{pH}$ of the enhanced ammonium nutrient solution decreased to $\mathrm{pH} 3$ in some cases. Thus, the masking of salinity effects by the effects of acidity could be a reason for the apparent lack of sensitivity to salinity in enhanced ammonium nutrition. On the contrary, Speer and Kaiser (1994a) reported that ammonium nutrition which had no negative effect on plant biomass production drastically increased the sensitivity of pea plants to $50 \mathrm{mM} \mathrm{NaCl}$ (moderate salinity). It was suggested that the lower intracellular compartmentation capacity of ammonium-fed pea plants compared to that of nitrate-fed plants was responsible for the higher sensitivity (Speer and Kaiser, 1994b).

The extent of $\mathrm{pH}$ decrease observed in enhanced ammonium nitrogen solutions was similar in any treatment, although the decrease was somewhat larger in cucumber than soybean. Because increases in proton activity ( $\mathrm{pH}$ decreases) are almost parallel to the amount of ammonium ion absorbed by plants from nutrient solution containing ammonium nitrogen (Breteler, 1973), it is assumed that the absorption of ammonium nitrogen may not be restricted by the supply of salts.

Al-Mutawa and El-Kantony (2001) reported that two wheat cultivars exhibited greater tolerance to $\mathrm{NaCl}$ in nitrate nutrition than in ammonium nutrition. They also suggested that in the case of $\mathrm{NaCl}$ salinity, the lower $\mathrm{K} / \mathrm{Na}$ ratio observed in ammonium-fed plants compared to nitrate-fed plants might be responsible for the low salinity tolerance in ammonium nutrition. When $\mathrm{NaCl}$ was added in our experiment, $\mathrm{Na}$ concentration did not increase in soybean leaves but increased in cucumber leaves irrespective of the nitrogen source. Consequently, $\mathrm{K} / \mathrm{Na}$ ratios did not decrease in soybean leaves, but did decrease markedly in cucumber leaves. In addition, cucumber leaves had much larger $\mathrm{K} / \mathrm{Na}$ ratios than soybean leaves. These results suggest that growth suppression caused by $\mathrm{NaCl}$ salinity might not be due to low $\mathrm{K} / \mathrm{Na}$ ratios in nutrient balance especially in leaves. Although soybean growth was suppressed more in $50 \mathrm{mM} \mathrm{NaCl}$ than in $25 \mathrm{mM} \mathrm{NaCl}, \mathrm{Cl}$ concentrations for both salinity treatments were similar in the case of nitrate nutrition. Hence, the high observed concentrations of $\mathrm{Cl}$ in soybean leaves might be excluded as being a reason for growth suppression in $50 \mathrm{mM}$ $\mathrm{NaCl}$.

Changes in the accumulation of $\mathrm{Na}, \mathrm{Ca}$ and $\mathrm{Cl}$ in leaf parts affected by respective salt treatments were similar between nitrate nutrition and enhanced ammonium nutrition in soybean and cucumber plants, although plant growth was inhibited by enhanced ammonium nutrition with or without added salts. These results suggest that the presence of ammonium at the present concentration in the nutrient solution would not suppress uptake of $\mathrm{Na}$ and $\mathrm{Ca}$ that were added at high concentrations in the salinity treatments. Low accumulation of $\mathrm{K}, \mathrm{Ca}$ and $\mathrm{Mg}$ in whole plant in enhanced ammonium nutrition compared to nitrate nutrition can be accounted for by lower dry matter production in 
enhanced ammonium nutrition.

\section{REFERENCES}

Al-Mutawa, M. M. and T. M. El-Katony 2001 Salt tolerance of two wheat genotypes in response to the form of nitrogen. Agronomie, 21: 259-266

Ashraf, M. 1999 Interactive effect of salt $(\mathrm{NaCl})$ and nitrogen form on growth, water relations and photosynthetic capacity of sunflower (Helianthus annuus L.). Ann. Appl. Biol., 135: 509-513

Ashraf, M. and R. Sultana 2000 Combination effect of $\mathrm{NaCl}$ salinity and nitrogen form on mineral composition of sunflower plants. Biol. Plant., 43: 615-619

Bourgeais-Chaillou, P., F. Perez-Alfocea and G. Guerrier 1992 Comparative effects of N-sources on growth and physiological responses of soybean exposed to NaCl-stress. J. Exp. Bot., 43: 1225-133

Breteler, H. 1973 A comparison between ammonium and nitrate nutrition of young sugar-beet plants grown in nutrient solutions at constant acidity. Neth. J. Agric. Sci., 21: 227-244

Cataldo, D. A., L. E. Schrader and V. L. Young 1974 Analysis by digestion and colorimetric assay of total nitrogen in plant tissues high in nitrate. Crop Sci., 14: 854-856

Dabuxilatu and M. Ikeda 2003 Differential effects of $\mathrm{NaCl}$ and $\mathrm{CaCl}_{2}$ on the incidence of salt injury and element accumulation in soybean and cucumber plants. Jpn. J. Soil Sci. Plant Nutr., 74: 459-465 (in Japanese)

Downs, R. J. and H. Hellmers 1975 Water and Nutrition. In "Environments and its experimental control of plant growth", Academic Press, London, pp. 95-116

Hawkins, H. -J. and O. A. Lewis 1993 Combination effect of $\mathrm{NaCl}$ salinity, nitrogen form and calcium concentration on the growth, ionic content and gaseous exchange properties of Triticum aestivum L. cv. Gatoos. New Phytol., 124: 161-170

Ikeda, M., K. Mizoguchi and T. Yamakawa 1992 Stimulation of dark carbon fixation in rice and tomato roots by application of ammonium nitrogen. Soil Sci. Plant Nutr., 38: 315-322

Leidi, E. O., M. Silberbush and S. H. Lips 1991 Wheat growth as affected by nitrogen type, pH and salinity. I. Biomass production and Mineral Composition. J. Plant Nutr., 14: 235-246

Lewis, O. A. M., E. O. Leidi and S. H. Lips 1989 Effect of nitrogen source on growth response to salinity stress in maize and wheat. New Phytol., 11: 155-160

Munns, R. 2002 Salinity, Growth and Phytohormons. In "Salinity: environments- plants-molecules", ed. by A. Lauchli and U. Luttge, Kluwer Academic Publishers, Dordrecht, pp. 229-248

Silbebush, M. and S. H. Lips 1988 Nitrogen concentration, ammonium/ nitrate ratio and $\mathrm{NaCl}$ interaction in vegetative and reproductive growth of peanuts. Physiol. Plant., 74: 493-498

Speer, M., A. Brune and W. M. Kaiser 1994 Replacement of nitrate by ammonium as the nitrogen source increases the salt sensitivity of pea plants. I. Ion concentrations in roots and leaves. Plant Cell Environ., 17: 1215-1221

Speer, M. and W. M. Kaiser 1994 Replacement of nitrate by ammonium as the nitrogen source increases the salt sensitivity of pea plants. II. Inter- and intracellular solute compartmentation in leaflets. Plant Cell Environ., 17: 1223-1231

Van Beusichem, M., E. Kirkby and R. Baas 1988 Influence of nitrate and ammonium nutrition on the uptake, assimilation, and distribution of nutrients in Ricinus communis. Plant Physiol., 86: 914-921

Walch-Liu, P., G. Neumann, F. Bangerth, and C. Engles 2000 Rapid effects of nitrogen form on leaf morphogenesis in tobacco. J. Exp. Bot., 51:227-237 